\title{
IMPROVING STUDENT TEACHERS' DIGITAL PEDAGOGY THROUGH MEANINGFUL LEARNING ACTIVITIES
}

\author{
${ }^{1}$ Siti Nazuar Sailin \& Noor Aida Mahmor \\ School of Education and Modern Languages, College of Arts and \\ Sciences, Universiti Utara Malaysia, Malaysia
}

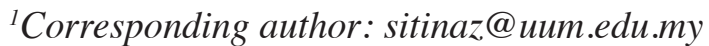

Received: 18 April 2018 Revised : 13 November 2018 Accepted: 25 November 2018

\begin{abstract}
Purpose - This study aims to examine the attributes of meaningful learning that student teachers perceived as enabling them to improve their digital pedagogy. It is concerned with how the meaningful learning activities help to prepare student teachers to successfully integrate digital technologies in their future teaching practice.

Methodology - This study adopted a qualitative research design and was underpinned by a meaningful learning theory as the theoretical and analytical framework. A total of 24 final year student teachers participated in this study. Data were mainly collected through student teachers' reflections regarding their learning experience. Thematic analysis was utilized to analyze and present the findings.

Findings - The findings offer some important insights into how the learning activities carried out in this Scholarship of Teaching and Learning (SoTL) project have directly and indirectly accelerated the acquisition of all the five attributes of meaningful learning. The findings of this study reveal that meaningful learning activities contribute to the improvement of the student teachers' knowledge of and skills in using Web 2.0. This improvement has boosted their confidence to integrate digital pedagogy in future teaching practices. The findings also indicate that although student teachers value their experiences in meaningful learning activities, they have some concerns regarding firstly, their capacities in applying digital pedagogy and secondly, the practicality of integrating Web 2.0 tools in the school setting because of several inherent limitations.
\end{abstract}


Significance - Meaningful learning activities when incorporated into teacher training programmes will expose student teachers to authentic experiences which will be beneficial for their own learning and future teaching practice.

Keywords: SoTL, meaningful learning, active learning, collaborative learning, digital pedagogy, technological pedagogical knowledge, Web 2.0 Tools, project-based learning, student teachers.

\section{INTRODUCTION}

The current generation of students are digital natives who grow up with digital technologies. They are tech-savvy as they think and process information differently from their predecessors (Bolton, Parasuraman, Hoefnagels, Migchels \& Kabadayi, 2013; Prenksy, 2001; Venter, 2016). They are confident in using new technologies such as the Internet, videogames, mobile technologies and other "tools of the digital age" (Prenksy, 2001, p. 1). Education systems all over the world are rapidly changing to keep pace with the latest technology and pedagogical innovation and making thorough preparations to meet the $21^{\text {st }}$ century learning expectations of the digital natives. Partnership for $21^{\text {st }}$ Century Learning (2015) posits that $21^{\text {st }}$ century students must be able to use technology to learn content and skills so that they will know how to learn, think critically, solve problems, use information, communicate, innovate and collaborate. Thus, teachers of the $21^{\text {st }}$ century are expected to enhance students' $21^{\text {st }}$ century skills through the use of appropriate digital technology and pedagogical innovation. The $21^{\text {st }}$ century teaching and learning (T\&L) process must shift from the conventional teacher-centered approach to a more constructivist learner-centered approach. Through such an emphasis on learner-centered education, knowledge is actively constructed through meaningful learning experiences and this will empower students to learn on their own.

In line with current development, Web 2.0 technology has become one of the major interests in pedagogical innovation. Researchers in the field of educational technology advocate that teachers should consider integrating Web 2.0 tools into their T\&L to support constructivist and meaningful learning. One of the potential benefits of Web 2.0 is to support meaningful learning through participation in collaborative environments such as blogs and wikis in which 
students have the opportunity to become the owner, creator and contributor of the web content and knowledge (Davies \& Merchant, 2007; Jimoyiannis, Tsiotakis, Roussinos \& Siorenta, 2013; Sailin \& Mahmor, 2017). However, in order to be able to integrate Web 2.0 technology into their teaching practice, teachers need knowledge, skills, and experience with Web 2.0. Yuen, Yaoyuneyong \& Yuen (2011) in their findings on teachers' perceptions, interest and use of Web 2.0 conclude that although teachers have positive perceptions and interest to integrate Web 2.0, they require more experience in using Web 2.0 tools in the classroom.

The need for teachers who are capable of designing $21^{\text {st }}$ century learning using the appropriate technology and pedagogical innovation is also in line with the Malaysian ICT agenda. The policy on ICT in the Malaysian education system emphasizes the integration of ICT in mainstream education with a view to promoting creativity, thinking skills, reasoning ability, and innovation in using ICT. This aim is manifested in the Education Development Plan for Malaysia 2001-2010. The three-pronged approach are as follows: to intensify the development of ICT infrastructure by expanding access to ICT facilities, to ensure equity in the provision of ICT facilities, and to develop an ICT-based curriculum (Ministry of Education, 2010). Hence, online learning has become an integral pedagogical tool to enhance the quality of teaching and learning at all levels of education in Malaysia (Ministry of Education, 2015).

In this regard, this study is concerns with addressing the need for teachers to effectively integrate the necessary experience, knowledge and skills in Web 2.0 technologies in their teaching and learning repertoire. We argued that it will be valuable for student teachers to be involved in meaningful learning activities with Web 2.0 not only to construct their own knowledge and understanding about Web 2.0 , but also to apply this digital pedagogy in their future teaching practice.

\section{LITERATURE REVIEW}

\section{Web 2.0 Technology}

Over the years, Web 2.0 has made its way into many spheres of our lives, including education. Web 2.0 technologies are generally associated with a variety of web platforms which emphasize user- 
generated content, participatory use and collaboration (O'Reilly, 2005). According to Jimoyiannis, et al., (2013), "Web 2.0 has been transformed from a space where users passively retrieve information, delivered by a small group of experts (Web 1.0), to a participatory, read/write platform (Web 2.0) which broadens users' communication capabilities and enables content distribution, sharing, co-creation, and remixing through participatory practices (p. 248)." These technologies are gaining reputation in the education context. Web 2.0 technologies such as social networking applications, blogs, wikis, web-based presentation tools, and online mind mapping tools have become important approaches in teaching and learning. Richardson (2009) asserted that Web 2.0 has the potential to create more interactive and responsive learning environments in which learners actively engage in the learning process through knowledge creations and evaluations. Moreover, the participatory capabilities of Web 2.0 encourage an active learning process and stimulate learners' thinking skills, as learners have the ability to regularly compare and respond to their own contributions or ideas in relation to those of their peers (Davies \& Merchant, 2007; Richardson, 2009; Sailin \& Mahmor, 2017).

\section{Digital Pedagogy with Web 2.0}

Being digital natives, students have constant interactions with technology. This means that they will have the opportunity to be empowered in their learning, especially when they have access to the Internet (Bolton, et al., 2013; Prenksy, 2001; Venter, 2016). It also means that teachers will have bigger challenges and responsibilities to engage their students in the teaching and learning process. Literature suggests that the greatest challenge to teachers in the $21^{\text {st }}$ century is their ability to meaningfully integrate technology into their teaching practice. In order to teach in the rapidly evolving educational landscape of the $21^{\text {st }}$ century, teachers must possess good technological pedagogical and content knowledge (Ertmer \& Otenbreit-Leftwich, 2010) or digital pedagogy (Milton \& Vozzo, 2013).

Milton and Vozzo (2013) define digital pedagogy as teacher's construction of knowledge through planning for learning which is based on problem-solving and higher order thinking skills. These skills help develop students' critical analysis, metacognition, and reflection through creating, editing and publishing online. This suggests that teachers have to constantly improve their pedagogy to keep up with the latest technology. Teachers need to provide an 
interactive and meaningful learning experience for their students. Thus, teachers need to be creative and innovative in designing their instructional strategies. The integration of digital pedagogy using Web 2.0 tools in the teaching and learning repertoire is an example of a pedagogical innovation which teachers can adopt, as it affords an excellent opportunity for knowledge construction and higher order thinking through digital creation, online collaboration and sharing (Jimoyiannis, et al. 2013; Hamdan, et al. 2013; McLoughlin \& Lee, 2010; Sailin \& Mahmor, 2017).

Ertmer \& Otenbreit-Leftwich (2010) suggests that to be able to fulfill the needs of $21^{\text {st }}$ century learning and to facilitate meaningful learning, teachers must understand how to use technology so that they can help students to construct deep and connected knowledge that can be applied in real situations. It is the responsibility of teacher educators to prepare their student teachers to become effective $21^{\text {st }}$ century teachers who are capable of integrating digital pedagogy in their classrooms. Teacher educators should ensure that the necessary support and enrichment for digital pedagogy is an integral aspect of the teacher preparation course. Therefore, this study aims to examine how meaningful learning activities can contribute to the development of student-teachers' knowledge of and skills in digital pedagogy and thus enabled them to successfully integrate Web 2.0 technology in their future teaching practice.

\section{THE THEORETICAL FRAMEWORK}

\section{Meaningful Learning}

This study is underpinned by the constructivist perspective of meaningful learning (Mayer, 2002; Jonassen, et al., 2003; Howland, Jonassen \& Marra; 2012). Constructivists generally assert that students construct their own understanding and knowledge of the world through experience and by reflecting on those experiences. According to Mayer (2002, p. 227), meaningful learning involves the construction of knowledge, whereby students make sense of their experiences by engaging in active cognitive processing, such as paying attention to relevant incoming information, mentally organizing incoming information into a coherent representation, and mentally integrating incoming information with existing knowledge. This view is in line with the assertion made in Jonassen, Howland, Moore, and Marra (2003,p.9) when they pointed out that meaningful learning occurs within "knowledge construction, not reproduction; 
conversation, not reception; articulation, not repetition; collaboration, not competition; reflection, not prescription" (Jonassen et al., 2003, p.15).

There are five attributes of meaningful learning, namely active, constructive; intentional, authentic, and cooperative (Jonassen, et al, 2003; Howland, Jonassen \& Marra, 2012). The characteristics of each attribute are simplified in Table 1 below. These characteristics of meaningful learning serve as the theoretical and analytical framework underpinning this particular study.

Table 1

Characteristics of Meaningful Learning Attributes (Adapted from Jonassen, et al., 2003; Howland, Jonassen \& Marra, 2012).

\begin{tabular}{ll}
\hline Attributes & Characteristics \\
\hline Active & $\begin{array}{l}\text { (Manipulative/Observant) } \\
\text { Students are dynamic. They are not passive } \\
\text { listeners but play active roles in learning activities, } \\
\text { actively manipulating objects and information, and } \\
\text { observing results from the learning activities. }\end{array}$ \\
Constructive & (Articulative/Reflective) \\
& $\begin{array}{l}\text { Students construct their own understanding and } \\
\text { knowledge, reflect and articulate their personal } \\
\text { understandings of phenomenon/activities observed. }\end{array}$ \\
Authentic & $\begin{array}{l}\text { (Complex/Contextual) } \\
\text { Students engage in authentic tasks and problems } \\
\text { rather than memorizing abstract concepts and ideas; } \\
\text { solving real-life problems. } \\
\text { (Goal-directed/Regulatory) }\end{array}$ \\
& $\begin{array}{l}\text { Students set their learning goals and plan their } \\
\text { learning pathways. } \\
\text { (Collaborative/Conversational) }\end{array}$ \\
Cooperative & $\begin{array}{l}\text { Students work with peers to solve problems/tasks } \\
\text { through collaborative activities and discussions to } \\
\text { better learn and apply their knowledge. }\end{array}$ \\
\hline &
\end{tabular}




\section{Meaningful Learning with Web 2.0 Technology}

It has been argued that meaningful learning occurs when learners are active, constructive, intentional, cooperative, and work on authentic tasks with digital technology (Jonassen et al., 2003; Ashburn \& Floden, 2006), including the Web 2.0 technologies (Howland, Jonassen \& Marra, 2012). Web 2.0 has become an important tool to support meaningful learning through various activities (Howland, Jonassen \& Marra, 2012; Hamdan et al., 2013; Jimoyiannis et al., 2013). For instance, the integration of Web 2.0 tools such as wikis, blogs, and social networking applications encourage more active participation and learning engagement. Students no longer use Web 2.0 to solely obtain information, but to actively create information and share it with others (Baltaci-Goktalay \& Ozdilek, 2010; Leh, et al., 2012).

In addition, the integration of Web 2.0 technologies in T\&L has the capacity to support active and meaningful learning through interactions and collaborations (An et al., 2009; Polin \& Light, 2010). It also provides opportunities for an authentic learning experience through experimentation and action or learning by doing (Lombardi, 2007; Sailin \& Mahmor, 2017). Most importantly, learning activities conducted using Web 2.0 technologies could provide opportunities to scaffold learning that is crucial for higher order thinking (McLoughlin \& Lee, 2010). Web 2.0 also has the potential to provide more interactive and customized learning environments where students could actively create their own knowledge, rather than passively receive information from the teachers. Through the use of Web 2.0 applications such as blogs, students may enhance their writing and thinking skills, as they construct their understanding of particular issues through collaborative writings. For example, Leh, et. al, (2012) found that the use of blog support knowledge creation and enhance learners' writing and technology skills. In addition, the study also found that students' motivation increases when they use blogs to submit their assignments because they have full ownership and control of their assignment presentations (Leh, et. al, 2012). These activities when integrated into the classroom would consequently improve students' interaction, communication, and collaboration.

The pedagogical benefits of integrating Web 2.0 in the T\&L process have been widely discussed in the literature. However, in Malaysia, the integration of Web 2.0 technology in teaching and learning is still in its infancy (Ismail \& Harun, 2010). Teachers and students mostly use Web 2.0 tools such as Facebook, Twitter, and Instagram 
in their daily lives for social networking (Yuen, Yaoyuneyong \& Yuen, 2011). The literature also suggests that many teachers are reluctant to integrate Web 2.0 technologies due to their lack of knowledge and skills, limited digital pedagogy, limited technology support and other institutional barriers (Pritchett, Pritchett \& Wohleb, 2013; Ahmed, Abdel-Almuniem, \& Almabhouh, 2016).

\section{Purpose and Rationale of the Study}

To meaningfully integrate digital pedagogy in teaching and learning is not an easy task. This is because teachers must have the knowledge about, and confidence and belief in using a particular technology. These are important factors that will determine teachers' attitudes in integrating technology (Ertmer \& Otenbreit-Leftwich, 2010). Albion (2008,p.21) suggests that "the best way for teachers to learn about Web 2.0 may be through learning with Web 2.0 as an authentic practice that can inform their planning and implementation of learning activities". Ertmer \& Otenbreit-Leftwich (2010) further explain that knowledge of technology is necessary, but it is not enough if teachers do not feel confident to use the knowledge to facilitate students' learning, a point which is especially relevant for novice teachers. In this regard, the student teachers need to develop not only knowledge about Web 2.0 technologies and digital pedagogy, but also to be confident in integrating these innovations successfully in their teaching and learning.

Realizing the benefits that Web 2.0 technologies have to offer and the types of challenges that teachers may face in their teaching practices, it is imperative to prepare our student teachers with the necessary digital pedagogy related to Web 2.0 for their future teaching practice. This study, therefore, attempts to answer the following research questions:

(i) What are the attributes of meaningful learning student teachers perceived as enabling them to improve their digital pedagogy?

(ii) How the meaningful learning activities used by the teacher educator have contributed to the development of student teachers' confidence in integrating digital pedagogy in their teaching practice?

\section{METHODOLOGY}

This study is designed within the framework of the Scholarship of Teaching and Learning (SoTL) research paradigm. According to 
Caroll (2004), SoTL is a systematic research approach that analyzes the teaching and learning process. SoTL encourages systematic academic inquiry into teaching and learning practices within the classroom and shares the findings with other academicians and practitioners for wider benefits (Felton, 2013). Hence, findings from a SoTL project can be critically reviewed by peers and can be built upon by others for further advancements. SoTL findings are open to the public through presentations and/or publications (Schulman, 2001).

Reflection is the heart and soul of SoTL as its practitioners "consciously reflect on the goals, methods, and strategies of teaching... and strive continuously to refine their teaching methods and effectiveness and explore new methods" (Belmont University, 2006, p. 57-58). Reflecting on teaching and trying to understand how students learn is crucial to SoTL research. In addition, through the SoTL process, "the participants have to articulate what the students do and what they do and the outcome as it relates to the teaching that makes the learning happen" (Raja Hussain, 2015, p. 32). Therefore, to ensure meaningful learning experiences for students, this study also emphasizes the importance of articulation and reflection in its design of the teaching and learning process.

There is a wide range of methodological approaches for conducting SoTL, and it can be either quantitative or qualitative in nature, or a combination of both (Hudball and Clarke, 2010). In this study, we adopted a qualitative approach in order to understand how meaningful learning activities could enhance the student teacher's digital pedagogy and their efficacy to integrate Web 2.0 technology in their future teaching practice. In this study, a qualitative methodology was chosen to conduct an in-depth exploration of the contemporary phenomenon (Creswell, 2005), that is the integration of digital pedagogy by using Web 2.0 technology which exists within the real-life context of the $21^{\text {st }}$ century teachers. In addition, the qualitative approach was used to better understand how through the reflections and critical reviews of the teaching and learning process, students learned from the perspectives of the students themselves, as well as from their instructors (Canning, 1991; Raja Hussin, 2015).

\section{Participants of the Study}

This study is about researching teaching and learning practices. Therefore, it involves both instructors and students. The first author is the primary researcher and the instructor of the course selected for this 
study. The student participants for this study were 24 final year student teachers from Universiti Utara Malaysia who enrolled in a 14-weeks course entitled Development of Web-Based Instruction. There were 16 female and eight male students within the age range 19-25 years old. They were in their final year of study, either majoring or minoring in Information Technology (IT). They were purposely selected based on their experience and background knowledge in IT. This is because their experience and background knowledge in IT could contribute towards shaping and accelerating their understanding and usage of digital pedagogy.

\section{Data Collection and Analysis}

The data sources used for this study comprised a preliminary survey, students' reflective writings, and the instructor's reflective writings and observation notes. Other data sources also included a rubric for the team-teaching presentations, photographs and video recordings of students' presentations. The collection of data was carried out over the period of 14 weeks. With the students' consent, the photographs and video recordings were taken during the students' team-teaching presentations. In the preliminary survey, students were required to provide feedback on their knowledge of Web 2.0 tools as well as the Web 2.0 tools that they had experienced and used in teaching and learning. As for the reflection, students were asked to reflect upon the techniques, methods and approaches integrated in their classrooms which would contribute to enhancing their digital pedagogy. Gibb's (1998) reflective cycle was used to formulate reflection questions to guide students in their reflective writing. The guided questions were crucial in guiding the reflective writing process in this SoTL project as the students were inexperienced in writing reflection, in particular about reflecting on specific learning activities such as team teaching. These guided questions allowed the students to think critically and analytically when writing their reflective journal. Both the questions and answers were written in the Malay language. The original Malay written responses constituted the data for analysis in this study. However, for the purpose of writing this report, the English language is used.

The thematic approach (Braun \& Clarke, 2006) was adopted to analyze the data. A total of 48 reflective writing journals from the students and two reflective writing journals were collected from the instructor of the course at the end of week 10 and 14. These 50 written reflections were then studied and analyzed by both researchers to determine the emerging theme/s. The emergent theme/s 
would then be coded. To establish trustworthiness and credibility, both researchers did a separate and independent analysis of the reflections and the emerging theme/s. Then, both researchers came together to match the codings carried out individually by each of the researchers, frequently checking and reviewing the interpretation of the data presented by each one of them. Each coding and statement obtained from the reflective writing were then verified. The major categories of the coding were predetermined from the five attributes of meaningful learning: active; constructive, authentic, intentional and collaboration. Nevertheless, small codes (or themes) were generated from the above major categories.

\section{Instructional Design of the Course}

In this SoTL project, the course was designed based upon the ADDIE instructional design model, underpinned by meaningful learning theory. The 14-weeks course was designed and conducted in five phases, as described in Table 2.

Table 2:

The Instructional Design of the SOTL Project based Upon the ADDIE model

\begin{tabular}{|c|c|c|}
\hline Phase & Activities / Task / Strategies & $\begin{array}{l}\text { Data } \\
\text { collection \& } \\
\text { Analysis }\end{array}$ \\
\hline Analysis & Preliminary analysis. & \multirow[t]{2}{*}{ Survey. } \\
\hline (Week 1) & $\begin{array}{l}\text { Instructor gathers information on } \\
\text { student's knowledge, skills and } \\
\text { confidence to integrate Web } 2.0 \\
\text { technology. }\end{array}$ & \\
\hline Design & Design a group project. & \multirow{2}{*}{$\begin{array}{l}\text { Observation } \\
\text { notes. }\end{array}$} \\
\hline (Week 2-4) & $\begin{array}{l}\text { Instructor briefs students about the } \\
\text { group project. Students form their } \\
\text { own groups of } 4 \text { to } 5 \text { people based } \\
\text { on their content area. Students have } \\
\text { to propose an educational website } \\
\text { of their chosen topic within their } \\
\text { content area (e.g.: Mathematics } \\
\text { or Business) using a Web } 2.0 \\
\text { application, namely Weebly. In this } \\
\text { phase, students have to come up } \\
\text { with a proposal and storyboard of } \\
\text { their proposed project. }\end{array}$ & \\
\hline
\end{tabular}


Phase

\begin{tabular}{|c|c|}
\hline Phase & Activities / Task / Strategies \\
\hline Development & Development of the WBI project. \\
\hline (Week 5-10) & $\begin{array}{l}\text { This is the major part of the } \\
\text { project. In this phase, students } \\
\text { work collaboratively with their } \\
\text { peers to develop the proposed } \\
\text { website. To cultivate meaningful } \\
\text { and active learning, during this } \\
\text { process, students are facilitated by } \\
\text { the instructor to learn and explore } \\
\text { several Web } 2.0 \text { tools that are } \\
\text { suitable to be integrated into the } \\
\text { teaching and learning process. } \\
\text { Students are also required to } \\
\text { incorporate other Web } 2.0 \text { tools in } \\
\text { the development of the website, } \\
\text { such as in preparing instructional } \\
\text { and assessment materials. }\end{array}$ \\
\hline
\end{tabular}

Implementation

(Week 11-13)

Evaluation

(Week 14)

\section{Teaching simulation.}

To see whether students are able to integrate the Web 2.0 tools in their teaching practice, each group will conduct a one-hour team teaching session of their selected topic (part of the WBI project). Each student will have to take part in the presentation. Students will be assessed based on their group and individual presentations.

\section{Evaluation of the teaching and learning process}

At the end of the course, students reflect on their learning process experience, their exploration of Web 2.0 and their integration of Web 2.0 technology. As a SoTL practitioner, the instructor also reflects on her teaching approach and collect evidence of the students' learning.

\section{Data collection \& Analysis}

Rubrics for WBI project.

\section{Reflection 1}

Student teacher's reflective writing.

Instructor's reflection.

\author{
Rubric for \\ Team Teach- \\ ing presenta- \\ tion. \\ Lesson Plan.
}

Reflection 2

Student teacher's reflective writing.

Instructor's reflection.

The instructional design of this course was developed to cater to the five attributes of meaningful learning which were integrated into the group project and team-teaching or teaching simulation activities. Within these activities, the instructor had diversified her teaching 
and learning strategies and these included student exploration of the topic area and peer learning which would have allowed students to actively engage in the learning process through collaboration and communication. Therefore, the researchers were able to explore how the five attributes of meaningful learning had occurred within the lesson and how they were perceived by the students.

\section{FINDINGS}

As pointed out in the introduction, this study aims to examine the attributes of meaningful learning that student teachers perceived as enabling them to improve their digital pedagogy. It is concerned with how the meaningful learning activities help to prepare student teachers to successfully integrate digital technologies in their future teaching practice. Following the ADDIE model, information on students' preliminary knowledge of Web 2.0 tools and applications were gathered at the beginning of the course (Phase 1). These included their knowledge, skills, and confidence to integrate Web 2.0 technology. The preliminary surveys revealed that student teachers were mostly familiar with popular social media applications such as Facebook, Instagram, and WhatsApp. Only when they were asked further about Web 2.0 tools for teaching and learning that they knew and have experienced with, and having provided them with some examples, only a few students mentioned tools such as Emaze, Prezi, Padlet and Weebly. These tools were mainly used by their lecturers in the courses they took in the previous semesters. This preliminary finding was not surprising as previous literature had reported that students mostly use Web 2.0 tools in their daily lives for social networking (Yuen, Yaoyuneyong \& Yuen, 2011). This finding from the preliminary surveys had provided a valuable input to the instructor to design the course project for the entire semester as outlined in Table 2 and to provide direction for answering the research questions.

In order to answer the first research question: What are the attributes of meaningful learning student teachers perceived as enabling them to improve their digital pedagogy?, the discussions of the findings are organized into several themes below.

\section{Attributes of Meaningful Learning Perceived by the Student Teachers}

In their reflections, students were asked to reflect through guided questions on how the pedagogical techniques used in the course 
helped to (a) enhance their knowledge and skills of using Web 2.0 tools; and (b) increase their confidence in integrating Web 2.0 tools in their teaching and learning. These guiding questions were asked so as to elicit students' response to the attributes of meaningful learning activities that helped improve their digital pedagogy.

As mentioned earlier, the major categories of coding are predetermined from the five attributes of meaningful learning: active; constructive, authentic, intentional and collaboration. Then, from the above major categories, small codes were generated. The five attributes of meaningful learning (i) active (ii) authentic and (iii) cooperative (iv) intentional and (v) constructive have emerged from the data (which mainly refer to the learning activities students were involved in), and will be organized according to the following themes: (1) exploratory learning; (2) peer learning; (3) learning by doing; (4) project-based learning; (5) team teaching; and (6) reflective practice. It was found that these attributes are intertwined in several meaningful activities, and therefore, may appear repetitively in several themes.

\section{Exploration and Peer Learning}

From the students' reflection, it can be seen that exploration and peer learning have emerged as the main learning activities that supported the active learning attribute. Keywords such as 'explore' and 'exploration' appeared several times in their reflective writings. One student wrote;

In this course, I gain new knowledge and experience. I explore many Web 2.0 tools. Honestly, before this, I only knew a few common tools such as Dropbox, Prezi, and BlogSpot. But now, I have explored other tools and platforms such as WordPress, Weebly, and Wix. I've explored almost 40 tools in this course. (ST\#18) (Translation)

Another student valued the knowledge and skills acquired from the exploratory learning process;

I tried to learn by myself, trying to explore each and every single button available in the application. At times, I do have low self-esteem when I first started using it, when things do not work out when I try to develop 
something in Weebly, this application turns to be very difficult to use... but now, I am happy to use all types of web 2.0 tools introduced in the course... Weebly, Padlet, Powtoon, Emaze, etc) especially when we were required to explore the applications by ourselves ( $S T$ \#12) (Translation)

As part of the exploratory learning process, students also highlighted the point that they learned through peer learning. In their exploration of Web 2.0 tools, students were able to work with peers, observed what others did, and learned from one another. They also sought help from their peers and the instructor. These are specifically reflected in their writings;

I have never used the application before, I received some help from my friends and lecturer to explore and use the application. (ST\#11) (Translation)

Because of the assignment given requires individual participation, I try to learn and explore by myself. I also get help from fellow friends and the instructor. (ST\#12) (Translation)

The above responses indicate that students perceived exploration and peer learning as important elements in learning Web 2.0 tools. As a result, these active learning activities lead to the students' satisfaction and active participation in the teaching and learning process. According to the meaningful learning model, manipulating information and resources and observing peers through exploration are important attributes of meaningful learning which contribute towards active learning.

As mentioned earlier, the instructor of this course adopted a studentcentered learning approach, which means that the instructor did not conduct any lecture or demonstration on how to use any particular Web 2.0 tools. However, during the face-to-face sessions, the instructor did introduce the students to some examples of Web 2.0 tools and allocated time for further exploration, peer sharing and discussion about Web 2.0 tools. It can be noticed that since the students were new to this type of instructional method, it created apprehensiveness among them and some students shared the view that the instructor should "teach how to use Web 2.0 tool during the 
class" while, for the rest of the students, they felt that "they have to explore the Web 2.0 tools by themselves". Despite these conflicting views, the students agree that at some point, they learn about using Web 2.0 from self-exploration and peers. Both independence and peer learning are characteristics of an active learning process for meaningful learning.

\title{
Project-based Learning and Learning by Doing
}

The authentic, cooperative and intentional learning attributes were mainly reflected in the project-based learning activity. As described in Table 2, students have to develop an educational website project in their respective groups. The educational website project was considered as authentic as it encouraged the students to create a tangible, useful and contextual educational website to be shared with others. In the students' reflections, it was evident that students valued the project-based learning as an authentic learning experience, and considered it beneficial for their future teaching practice. For example, one of the students wrote;

\begin{abstract}
The experience gained in developing a teaching website is a beneficial learning process and it brings many good things and knowledge to my life especially in my learning. Along the way, I learn to explore the functions of Web 2.0 application and I realize that there are many approaches that can be used in teaching and learning apart from using a textbook to make my lesson more interesting and making the students more excited to learn. (ST\#1) (Translation)
\end{abstract}

The project-based learning also helped to foster the cooperative learning attribute where students worked collaboratively with peers in accomplishing their group project. Collaboration occurs in many activities throughout the semester, especially during designing and writing up the project proposal and storyboard, and discussing and making a decision on which Web 2.0 tools were suitable to be integrated into their educational website project. One student wrote;

Every group member gives idea and opinions about the tools to all group members. If there is any of the group members do not know about anything, the other 
members will help to explain and sort the problem. Understanding is formed and each decision is made together such as by drawing lots to decide on the topic or assignment given. (ST\#2) (Translation)

Through this project-based learning, students also realized that cooperative learning through collaboration and conversational activities among group members were important in generating ideas for completing their group project. In this study, students reflected that they discussed and worked together in designing, compiling, editing and developing the educational website with their group members to come up with interesting projects. They also worked together to integrate their project in the teaching simulation.

This course requires us to complete the assigned task in groups. When we gather to discuss the task, all group members will give ideas, opinions, and suggestions. Sometimes, I myself could not even think about the ideas suggested. Every group member has to do the task given to them. At times, my ideas were not accepted by the group. Thus, I seek advice and opinions from other group members. It was not disappointing at all; their cooperation in giving ideas can stimulate my creativity in producing better presentations using PowToon, Emaze and many others. It was so touched; the collaboration among group members was amazing and was not limited by time. We did it together. I will never forget this experience. (ST\#11) (Translation)

The project-based learning also supported the embodiment of the intentional learning attribute. Students' reflections on the learning process showed that they took charge of their own learning, which seemed to suggest a goal-directed and self-regulatory learning process. During the process, the instructor did not assign any specific task to any individual students in any of the group projects. It was the students themselves who delegated the tasks among themselves to complete their project.

We delegate task equally among group members in order to be fair to everyone. Each member has to perform their best in completing their task. Should there be any mistakes or any incomplete information, we will advise 
and correct the mistakes. If we lack ideas, we will sit down and try to get the best ideas. (\#14) (Translation)

However, the instructor had noticed that a few students did not give their full commitment to the group work. There was one group of students who had problems doing their group work. For example, the delegation of the task process had caused some of the group members to ignore the types of applications used by the other group members. They were working individually based on the given task only. One of the student group members took note of this in his reflection:

\begin{abstract}
Some of the group members did not give their full commitment to the group work. Apart from that, there were also differences in opinions which resulted in unsatisfactorywork. This happens because each member has different taste and interest. But finally, after seeking advice from the lecturer, we manage to share new ideas with the group members. (ST\#18) (Translation)
\end{abstract}

As an intervention, this particular group received facilitation from the instructor after one of the group members reported to her their problems. After several meetings with the instructor, the group members began to show improvements in terms of involvement.

Hence, project-based learning activities are authentic in nature as the students will face real-life situations and deal with the problems that will arise while developing and completing the project. Consequently, it should be noted that students were able to set their own learning goals and planned their learning pathways such as coming up with proposals, design, and construction as well as the development of ideas. These learning characteristics are known as 'Intentional' which is one of the five major attributes as suggested by Jonassen, et al. (2003) and Howland, Jonassen \& Marra (2012). It is imperative to note that the intentional attribute was not apparent in the students' reflections, but it can be identified through the researcher's observation and reflection of the students' learning. It is also important to note that, within the project-based learning activity, students were actually engaged in learning by doing. They were involved in many collaborative and hands-on tasks in order to develop a given project. Hence, these tasks supported the active learning which is one of the attributes of meaningful learning. 


\section{Team-Teaching Simulations}

Upon completion of the website project, the students were required to conduct a one-hour team teaching simulation whereby they had to integrate the Web 2.0 tools that they had explored or developed in their website. It was found that the knowledge and skills about Web 2.0 tools that the student teachers discovered and developed throughout this course had contributed to the development of their digital pedagogy. This was clearly evident during their teamteaching simulation in which several Web 2.0 tools such as Emaze, PowToon, Popplet, Padlet, Cogongc, Linoit, Rawshort, and Visme were demonstrated and integrated into the presentation. Importantly, the team-teaching activity provided an avenue for students to experience the active, authentic and cooperative learning attributes of meaningful learning. Hence, improving students' knowledge, skills and confidence in integrating Web 2.0 in the teaching and learning.

Doing team-teaching with friends, I have gained so many inputs... I know how to diversify teaching techniques using Web 2.0. Learning becomes more interactive because students can explore the website provided (ST\#2) (Translation)

Team-teaching is one of the methods that can be used to measure collaboration among groups apart from an individual's abilities to move forward. This method is suitable for increasing my confidence level. Apart from that, it provides exposure to me and my friends regarding the real situation of teaching and learning at school (ST\#4) (Translation)

From the analysis of the student teachers' reflection, it was also found that the team-teaching simulation provided opportunities for students to indulge in in-depth discussions and to work together; which are basically the main elements of cooperative learning attributes as have been pointed out by Jonassen, et al. (2003) and Howland, Jonassen \& Marra (2012).

As a group, we work very hard to complete our micro teaching presentation assignment. Each one of us strives to give the best ideas to bring the best out of our team-teaching (ST\#12) (Translation) 
Me and my group members work together in doing the presentation in the classroom. Each of us was assigned a specific task and we did the task assigned (ST\#20) (Translation)

\section{Reflective Writings}

The constructive element is another attribute that can be identified through the researcher's observation and reflection of students' learning. The constructive attribute appeared when students used their metacognitive skills such as articulating their ideas and reflecting on their learning process. In this SoTL project, the reflective writing was a part of the required learning activities whereby students had to reflect upon the techniques, methods, and approaches integrated into the classroom which would contribute to enhancing their digital pedagogy. Although students were involved in the reflective writing process which contributed to the constructive attribute of meaningful learning, it was found that students were still lacking in reflective skills. Gibb's (1998) suggested a reflective cycle comprising six components: description, feeling, evaluation, analysis, conclusion, and action plan. However, from the analysis of the students' reflective writing, on most occasions, students were merely reporting their feelings and describing the process instead of critically reflecting on the process. Their reflective writings were lacking in terms of evaluation, analysis, conclusion, and action plan.

\section{Confidence in Integrating Digital Pedagogy}

The following discussion addresses the second research question, which is to understand how the elements of meaningful learning activities help to improve student teachers' confidence in integrating digital pedagogy. Analysis of student teachers' reflection triangulated with the instructor's observation of students' participation and engagement. It was found that the five meaningful learning attributes - active, authentic, cooperative, intentional and constructive that students had experienced through exploratory learning, peer learning, learning by doing, project-based learning, team teaching, and reflective writing contributed to the development of students' confidence in integrating digital pedagogy in their future practice.

In the students' reflections, it can be seen that they valued the meaningful learning activities that they had been experiencing in the 
course such as the exploratory approach, collaborative group work, and the team teaching.

\begin{abstract}
After attending this course, I'm confident that I can vary my teaching pedagogy using Web 2.0. The experience that I gain through this course has opened my mind on how to integrate technology in different ways. (ST\#2) (Translation)
\end{abstract}

I can now figure out which Web 2.0 that is suitable to be integrated into my future $T \& L$ because I've known the advantage and disadvantages of the tools (ST \#8) (Translation)

For most of the students, it was their first time involved in an authentic project to develop an educational website and integrate it into their teaching practice. However, it was evident that throughout the course, students gained confidence to integrate digital pedagogy and showed their excitement towards integrating it in their future teaching practice.

At first, I feel like I know nothing about Web 2.0. I've heard about Weebly before, but I never used it. But in this course, I've to explore Weebly and other Web 2.0 tools and collaborate with my groupmate to come up with the WBI project. Now, I feel so passionate to integrate Web 2.0 tools such as Padlet, PowToon, Emaze, and others. (ST\#15) (Translation)

Most importantly, during the teaching simulations, students were able to demonstrate their ability to choose what and which Web 2.0 tools would be suitable for different teaching and learning requirements and this reflected a significant development of their digital pedagogy.

The team teaching increases my confidence to teach, and how to manage the use of Web 2.0 in the classroom. Any challenges in using Web 2.0 during the team teaching can be solved with proper planning. So, if we face the same problem in our (future) class, we know how to manage it. (ST\#8) (Translation) 
The project-based learning that required students to work collaboratively had also contributed to their confidence in integrating digital technology.

Working in a group is better than working alone. Working in a group gives me confidence during the integration of web 2.0. In the group, we discuss how to enhance the presentation methods in front of the class. We use SlideShare for explaining; use Pinterest for individual quiz; and Videopad for doing other works among group members. (ST\#2) (Translation)

Hence, the findings clearly showed that the students' confidence level had increased when the five meaningful learning attributes were integrated by the instructor in the classroom. The students not only acquired collaborative skills, but they also enhanced their pedagogical knowledge regarding the use of Web 2.0 tools in the classroom. Students showed more confidence in using the tools and demonstrated the ability to choose the most appropriate tool for the task at hand.

\section{DISCUSSION}

The objective of this SoTL project is to prepare student teachers with the necessary technology and pedagogical knowledge related to using Web 2.0 technology in teaching and learning, or digital pedagogy for their future teaching practice. This study has shown that student teachers were able to demonstrate that they were becoming increasingly confident in selecting, using and integrating digital pedagogy. The engagement and involvement of student teachers were assessed through various learning activities, including WBI project development, discussions, and team teaching presentations. Throughout the course, as the student teachers were exploring more Web 2.0 tools for designing their WBI project, they were developing their knowledge and skill about Web 2.0. The students also managed to come up with an informative and interactive WBI site using a Web 2.0 platform, namely Weebly. This improvement was also evident during the team teaching presentations in which students were able to integrate various Web 2.0 tools in the T\&L process. This finding is in line with the previous studies that found the integration of Web 2.0 into teaching and learning provides an authentic learning experience 
for student teachers in their preparation to integrate technology in their future practice (Jimoyiannis et al., 2013).

\section{Attributes of Meaningful Learning}

From the study, it can be seen that all the five attributes of meaningful learning overlap and they appear or occur in almost every type of activities. The following discussion addresses all the five attributes of meaningful learning in relation to the six themes and activities dealt with in this study. The findings on active learning through exploration and peer learning imply that students in this study are involved in active learning through exploration of Web 2.0 tools. This is because the instructor allows the students to "explore" various types of Web 2.0 tools. As a result, student involvement and engagement became more dynamic. It was also observed by the instructor that the students are not merely passive listeners, but play active roles in the learning activities by actively exploring new tools and information and observing results from the learning activities. Students also actively work with peers and seek facilitation from the instructor. These types of learning activities that occurred are aligned with the theory of meaningful learning found in Jonassen, et al., (2003) and Howland, Jonassen and Marra (2012). It also provides further support that peer learning and the instructor's facilitation play an important role in promoting active and meaningful learning (Webb \& Moallem, 2016).

The meaningful learning approach through project-based activities also contributed to students' improvement in their digital pedagogy. It was observed by the instructor that students were working collaboratively with others, involved in designing and developing an educational website and actively learned by doing that promoted authentic learning experiences and consequently improved their digital pedagogy. Throughout the course, as the student teachers were exploring more Web 2.0 tools for designing their WBI project, it was observed that the students were also developing their knowledge and skill about Web 2.0. This was apparent at the end of the course where students managed to come up with an informative and interactive WBI site using Web 2.0 platform, namely Weebly. This improvement was also evident during the team teaching presentations in which students were able to integrate various Web 2.0 tools in the T\&L process. This is consistent with previous studies that suggest project-based learning as an effective approach 
in nurturing knowledge application (Hamdan et al., 2013; Husnin et al., 2013; Hodkiewicz, 2014; Mason, Shuman \& Cook, 2014).

In this study, the skills and knowledge that the students gained through exploration and peer learning were successfully applied in their group project and during the teaching simulation. The team teaching in teaching simulation becomes the major contributor in students' learning as it provides room for meaningful learning: active, constructive, authentic, intentional, and cooperative. Whereas, the reflective writing activity provides an opportunity for constructive learning as it allows student teachers to articulate their ideas and reflect on their own learning process. As future teachers, they should be able to reflect on their own practices for further improvement, which is important in their professional development (Yaacob et al, 2014). However, in this study, student teachers' reflections were merely reporting their learning activities and emotions which are usually characteristic of beginner reflective writers. This finding is consistent with the study by Yaacob et al (2014) which found that although prospective teachers carried out reflective writing in their journals, their reflections were not at the deepest level of insight. This finding provides important insights to the instructors that students need more facilitation in terms of producing reflective writing.

\section{Confidence in Integrating Digital Pedagogy}

The findings of this study also indicate that as the student teachers are gaining more knowledge and skills of Web 2.0 technologies simultaneously, they can also gain confidence to integrate these technologies and consequently improve their digital pedagogy. It was observed by the instructor that throughout the development of student projects, students were developing their digital technology skills through several meaningful learning activities, such as being actively involved in an authentic task and working collaboratively with others in designing and developing the educational website. These consequently improved their confidence to integrate Web 2.0 technology or their digital pedagogy. This finding corroborates the view held that for teachers to be able to adopt Web 2.0 technology in their teaching practice, they need to acquire the skills of using the technologies together with its specific pedagogical dimensions (Jimoyiannis, et. al., 2013; Milton \& Vozzo, 2013). This is also in line with the previous studies which suggest that knowledge, confidence, beliefs, and attitudes about a particular technology are key factors 
that influence teachers' decision in integrating technology (Albion, 2008; Ertmer \& Otenbreit-Leftwich, 2010). Student teachers also perceived that their improvement in digital pedagogy was the result of their involvement in authentic learning experiences: the project-based learning and team-teaching taught them important meaningful learning attributes. This is corroborated in Albion (2008, p.21) who suggest that authentic practice during the teaching and learning process will contribute to the teacher's future planning and implementation of digital learning activities.

\section{Challenges in Integrating Digital Pedagogy}

Despite student teachers' improvement in knowledge and skills and confidence to integrate Web 2.0 technology, there were concerns or issues raised by the student teachers. Most of the student teachers were apprehensive about not being able to integrate Web 2.0 in their future teaching due to the problem of limited Internet and technology access at school. This concern about limited Internet access was raised based on their experience during their teaching practicum prior to taking this course. Nonetheless, despite the concern raised, the student teachers demonstrated changes in their beliefs and confidence in integrating Web 2.0 tools essential for their professional development. Students are prepared with the necessary skills to overcome the challenges. During the teaching simulation, they managed to have a back-up plan which was normally a nontechnology approach, to ensure that the teaching and learning process proceeded smoothly. It was also evident during the team-teaching sessions in which students also used non-web technology-based teaching aids and activities, such as using the whiteboard and paper cuttings during the presentation, even though it was conducted in the computer laboratory with proper Internet access, LCD projectors, and personal computers. Based on their reflections, the non-web technology serves as a backup plan or alternative for them should there be no Internet access. They also took into consideration what they might be able to do in terms of integrating technology rather than depending upon technology infrastructure at schools. In terms of the challenges that student teachers have perceived when incorporating digital pedagogy using Web 2.0 in their future teaching practice, the finding from this study suggests that technology infrastructure and Internet access are key factors towards increasing teacher's confidence in integrating digital pedagogy in teaching and learning. This is consistent with the findings in previous studies which find 
that teachers who can access Internet both at home and school are the ones who demonstrate a high level of confidence in using ICT applications (Ismail, Azizan \& Azman, 2011).

Overall, student participation and engagement in this course were high, with active contributions from all students, especially in the development of the website project and team-teaching simulation. Previous studies highlighted the benefits associated with meaningful learning activities particularly in promoting active participation and engagement in the teaching and learning process (Baltaci-Goktalay \& Ozdilek, 2010; Leh, et al., 2012). In cognizant of these benefits, this SoTL project was intentionally conducted based upon the ADDIE model. The model has incorporated meaningful learning pedagogies and sought to engage students at a higher cognitive level. The findings of this study suggest that meaningful learning was achieved through active learning activities, whereby student involvement in the course is dynamic. They are not passive listeners but play active roles in the learning process, generate knowledge and understanding of the topics through exploration and observation of what their peers did throughout the learning process. The finding of this study also corresponds to the theory of meaningful learning, which asserts that through engagement and participation in meaningful learning activities students may enhance their knowledge and skills. In this study, the meaningful learning activities that include exploration, team teaching, and project-based learning that students went through in the course have provided a meaningful learning experience for students, and as a result they were able to integrate Web 2.0 technology in their future teaching practice. This finding corroborates that in the study by Hamdan et al. (2013) which found that there are positive relationships between the use of Web 2.0 tools and a teaching and learning process which is characterized by cooperative learning, intentional learning, authentic learning, and active learning.

In this study, the authentic task to collaboratively develop a WBI site that integrates Web 2.0 tools has enhanced the confidence of the student teachers and facilitated their meaningful learning in using Web 2.0 technology in their future teaching. In addition, the teamteaching simulations that integrated the use of Web 2.0 technology was particularly important in developing the students' confidence in integrating technology. This was because the student teachers were able to experience the delivery of a lesson that had integrated Web 2.0 technology and they could also observe what their peers did. The 
meaningful learning activities experienced by the student teachers in this course, such as through exploration and project-based learning has also cultivated independent learning skills. Students no longer have to rely on the instructor. In fact, the learning style has shifted from a teacher-centered to a more student-centered learning approach. With this kind of experience, student-teacher learns to scaffold, reflect and develop their digital pedagogy competencies (McLoughlin \& Lee, 2010; Tondeur, Aesaert, Prestridge \& Consuegra, 2018). Since Web 2.0 technologies are evolving, new tools and applications will emerge. Thus, student teachers definitely need to explore independent learning skills in order to grow professionally and to develop their knowledge and skills in digital pedagogy.

\section{CONCLUSION}

This SoTL project as a whole has contributed to our understanding of how student teachers may best learn how to develop digital pedagogy in their teaching practice. Being digital natives, these student teachers valued the meaningful learning activities that they had experienced throughout their course. The findings of this study imply that higher institutions of learning should consider including pedagogy for Web 2.0 technologies as a subject in designing their teacher education programme. Such a move will help teachers learn innovative teaching strategies which in turn, will build their confidence in incorporating digital pedagogy in their future teaching practice. Therefore, meaningful learning activities should be incorporated in teacher training programmes so as to expose teachers-to-be to the authentic experiences which will be beneficial for their own learning and their future teaching practice. Similarly, teacher educators should also be equipped with the skills in coaching and designing meaningful learning using digital technologies so that the desired learning outcomes for their charges will be successfully achieved. Future SoTL projects should emphasize the importance of improving student teachers' reflective practice as it will contribute to the professional learning of the student teachers in integrating digital pedagogy in their teaching practice.

\section{REFERENCES}

Ahmed, A. M., Abdel-Almuniem, A., \& Almabhouh, A. A. (2016). The current use of web 2.0 tools in university teaching from 
the perspective of faculty members at the college of education. International Journal of Instruction, 9(1), 179-194.

Yaacob, A., Walters, L. M., Md Ali, R, Shaik Abdullah, S. \& Walters, T. (2014). Reflecting on Malaysian teacher trainees' journals. Malaysian Journal of Learning and Instruction. 11 . 1-21

Ajjan, H., \& Hartshorne, R. (2008). Investigating faculty decisions to adopt web 2.0 technologies: Theory and empirical tests. Internet and Higher Education, 11, 71-80.

Albion, P. (2008). Web 2.0 in teacher education: two imperatives for action. Computers in the Schools, 25(3/4), 181-198.

Ashburn, E. A., \& Floden, R. E. (2006). Meaningful learning using technology: What educators need to know and do. New York: Teachers College.

Baltaci-Goktalay, S, \& Ozdilek, Z. (2010). Pre-service teachers' perceptions about web 2.0 technologies. Procedia - Social and Behavioral Sciences, 2, 4737-4741.

Bolton, R. N., Parasuraman, A., Hoefnagels, A., Migchels, N., Kabadayi, S., Gruber, T., Loureiro, Y. K., Solnet, D., (2013). Understanding generation $\mathrm{Y}$ and their use of social media: A review and research agenda. Journal of Service Management. 24(3). 245-267

Bonwell, C. C., \& Eison, J. A. (1991). Active learning: Creating excitement in the classroom.

ERIC Digest. Retrieved from: http://eric.ed.gov/?id=ED340272

Braun, V. and Clarke, V. (2006). Using thematic analysis in psychology. Qualitative Research in Psychology, 3 (2). pp. 77-101.

Canning, C. (1991). What teachers say about reflection. Educational Leadership, 48(6), 18-21.

Davies, J., \& Merchant, G. (2007). Looking from the inside out: Academic blogging as a new literacy. In M. Knobel \& C. Lankshear (Eds.), A new literacies sampler. New York: Peter Lang.

Ertmer, P. A., \& Ottenbreit-Leftwich, A. T. (2010). Teacher technology change: How knowledge, confidence, beliefs, and culture intersect. Journal of Research on Technology in Education, 42(3), 255-284.

Hall, R., \& Hall, M. (2010). Scoping the pedagogic relationship between self-efficacy and Web 2.0 technologies. Learning, Media and Technology, 35(3), 255-273.

Hamdan, N., P. McKnight, McKnight, K., \& Arfstrom, K. (2013). The flipped learning model: A white paper based on the literature 
review. The Flipped Learning Network. Retrieved from http:// www.flipped learning.org/cms/lib07/VA01923112/ Centricity/ Domain/41/WhitePaper_FlippedLearning.pdf

Hudball, H \& Clarke, A. (2010). Diverse methodological approaches and Considerations for SoTL in Higher Education. The Canadian Journal for the Scholarship of Teaching and Learning. 1(1). Article 2.

Husnin, H., Din, R., Karim, A, Norman, H., \& Hamdan, A. (2013). Assessing authentic learning via storyboarding: A Malaysian Perspective. Asian Social Science. 9(16).

Hodkiewicz, M. R. (2014). Insights gained from analysis of performance and participation in a flipped classroom. Education Research and Perspectives. 41, 254-284.

Howland, J., Jonassen, D.H. \& Marra, R.M. (2012). Meaningful learning with technology. (4th ed.). Columbus, $\mathrm{OH}$ : Merrill/ Prentice-Hall.

Ismail, M. T. \& Harun, J. (2010). Kajian tahap penggunaan web 2.0 dalam pembelajaran di kalangan murid sekolah menengah Daerah Kulaijaya, Johor. (Master's thesis), Universiti Teknologi Malaysia.

ISTE (2007). National Educational Technology Standards for Students. International Society for Technology in Education (ISTE). Retrieved from: http://www.iste.org/standards/ standards/standards-for-students

Jimoyiannis, A., Tsiotakis, P., Roussinos, D., \& Siorenta, A. (2013).

Preparing teachers to integrate Web 2.0 in school practice:

Toward a framework for Pedagogy 2.0. Australasian Journal of Educational Technology, 29(2), 248-267.

Jonassen, D.H., Howland, J., Moore, J., \& Marra, R.M. (2003). Learning to Solve Problems with Technology: A Constructivist Perspective (2nd. ed). Columbus, OH: Merrill/PrenticeHall.

Leh, A. S., Kremling, J., Nakayama, M., \& Newberry, B. (2012). Effects of the Use of the blog and discussion board on online teaching and learning. In Proceedings of Society for International Technology \& Teacher Education International Conference (SITE) March 2012 (pp. 574-579). Retrieved from https://www.learntechlib.org/p/39632/proceedings_39632. pdf

Light, D. \& Polin, D. K. (2010). Integrating Web 2.0 tools into the classroom: Changing the culture of learning. 
Lombardi, M. (2007). Authentic learning for the 21st century: An overview. Educause. Retrieved from http://alicechristie.org/ classes/530/EduCause.pdf

Markham, T., Larmer, J., \& Ravitz, J. (2003). Project based learning handbook: A guide to standards-focused projectbased learning (2nd Ed.). Novato, CA: Buck Institute for Education.

Mayer, R, E. (2002). Rote versus meaningful learning: Revising Bloom's taxonomy. Theory into Practice, 41(4), 226-232

McLoughlin, C. \& Lee, M. J. W. (2010). Personalised and selfregulated learning in the Web 2.0 era: International exemplars of innovative pedagogy using social software. Australasian Journal of Educational Technology, 26(1), 28-43.

Milton,M.(2013). Digital literacy and digital pedagogies for teaching literacy: Pre-service teachers' experience on teaching rounds. Journal of Literacy and Technology. 14(1), 72-97.

Ministry of Education (2010). Education Development Plan for Malaysia 2001-2010. Ministry of Education, Malaysia.

Ministry of Education (2015). Malaysia Education Blueprint 20152025 (Higher Education). Ministry of Education, Malaysia.

O'reilly, T. (2005). What is Web 2.0: Design patterns and business models for the next generation of software. O'Reilly Media Inc. Retrieved from: http://www.oreillynet.com/pub/a/oreilly/ tim/news/2005/09/30/what-is-web-20.html

Partnership for $21^{\text {st }}$ Century Skills (2002). A Report and MILE Guide for $21^{\text {st }}$ Century. Retrieved from http://www.p21.org/storage/ documents/P21_Report.pdf

Prensky, M. (2001). Digital natives, digital immigrants. On the Horizon. 9(5).

Pritchett, C. G., Pritchett, C. C., \& Wohleb, E. C. (2013). Usage, barriers, and training of Web 2.0 technology applications as reported by certified educators. SRATE Journal, 22(2), 29-38. Retrieved from http://files.eric.ed.gov/fulltext/EJ1015771. pdf

Raja Hussain, R. M. (2015). From just teaching to SoTL: PleaSE. Professorial Lecture Series. Sintok: UUM Press.

Richardson, W. (2009). Blogs, wikis, podcasts, and other powerful web tools for classrooms (2nd ed.). Thousand Oaks, CA: Corwin Press.

Sailin, S.N., \& Mahmor, N.A., (2017).Create-Share-Collaborate: An instructional strategy for developing studentteacher's critical thinking. $1^{\text {st }}$ Inspirational Scholar Symposium Proceedings. Universiti Utara Malaysia. (pp. 66-81). 
Subramanian, M. (2012). Journal writing as a tool for teacher trainees: Reflection on teaching. Retrieved from http://www. ipbl.edu.my.

Tondeur, J., Aesaert, K., Prestridge, S. \& Consuegra, E. (2018). A multilevel analysis of what matters in the training of preservice teacher's ICT competencies. Computers \& Education. $122,32-42$.

Venter, E. (2016). Bridging the communication gap between Generation $\mathrm{Y}$ and the Baby Boomer generation. International Journal of Adolescence and Youth. Retrieved fromhttp://dx.doi.org/10.1080/02673843.2016.1267022 Yuen, S. C. Y., Yaoyuneyong, G., \& Yuen, P. K. (2011). Perceptions, interest, and use: Teachers and web 2.0 tools in education. International Journal of Technology in Teaching and Learning, 7(2), 109-123. 